\title{
Promotion of Differentiated Instruction Through a Virtual Learning Environment
}

\author{
Promoción de instrucción diferenciada a través \\ de un ambiente de aprendizaje virtual \\ Promoção de instruções diferenciadas através \\ de um ambiente de aprendizagem virtual
}

\author{
Marolly Andrea Vargas-Parra ${ }^{1}$ \\ Javier Armando Rodríguez-Orejuela ${ }^{2}$ \\ Leonardo Herrera-Mosquera ${ }^{3}$
}

\section{Abstract}

This qualitative action research intends to analyze the effects of differentiated instruction (DI) administered through a virtual learning environment (VLE) on students' English learning process. Differentiated instruction is understood as an approach that aims to foster every student's potential by taking into account their level of readiness, learning styles, multiple intelligences and interests. A group of 29 students from a private school participated in this research study. Journals data were analyzed through the use of content analysis and triangulation techniques, using Atlas.ti software. Findings avowed that DI through a VLE approach (DI-VLE henceforth) had a positive impact on students' learning process, meeting their needs and increasing their motivation. This study suggests that teachers and researchers in Colombia implement $\mathrm{D}$ in their own practices to gain understanding of the advantages and disadvantages of this approach. The field of teaching English as a foreign language cannot be exception. The DI approach can constitute a valuable pedagogical alternative for the benefit of students.

\section{Keywords}

differentiated instruction (DI); virtual learning environment (VLE); english as a foreign language (EFL); language learning

\section{Resumen}

Esta investigación-acción cualitativa tiene como objetivo analizar los efectos de la instrucción diferenciada (ID) administrada a través de un ambiente de aprendizaje virtual (AAV) en el proceso de aprendizaje de los estudiantes de inglés. La instrucción diferenciada se entiende como un abordaje que busca fomentar el potencial de cada estudiante, teniendo en cuenta su nivel de preparación, hábitos de aprendizaje, inteligencias múltiples e intereses. Un grupo de 29 estudiantes de una escuela privada participó en este estudio. Se analizaron los datos de los diarios a través del uso de análisis de contenido y técnicas de triangulación con el software Atlas.ti. Como resultado, el ID a través del AAV (en adelante ID-AAv) tuvo un impacto positivo en el proceso de aprendizaje de los estudiantes al conocer sus necesidades y aumentar su motivación. Este estudio sugiere que los profesores e investigadores en Colombia deberían implementar el ID en sus propias prácticas para entender las ventajas y desventajas de este método. El campo de estudio del inglés como lengua extranjera no puede ser la excepción. El abordaje de la ID puede constituir una alternativa pedagógica valiosa para el beneficio de los estudiantes.

\section{Palabras clave}

instrucción diferenciada (ID); ambiente de aprendizaje virtual (AAV); inglés como lengua extranjera; aprendizaje de idiomas

1 Universidad Surcolombiana, Neiva, Colombia. Email: marolyta@hotmail.com

2 Universidad Surcolombiana, Neiva, Colombia. Email: javirodriguez_0701@hotmail.com

3 Universidad Surcolombiana, Neiva, Colombia. Email: leonardo.herrera@usco.edu.co 


\section{Resumo}

Esta investigação-ação qualitativa visa analisar os efeitos da instrução diferenciada (ID) ministrada através de um ambiente de aprendizagem virtual (AAV) no processo de aprendizagem dos estudantes de inglês. A instrução diferenciada é entendida como uma abordagem que procura encorajar o potencial de cada estudante levando em conta seu nível de preparação, hábitos de aprendizagem, inteligências múltiplas e interesses. Um grupo de 29 estudantes de uma escola privada participaram neste estudo. Analisaram-se os dados dos diários através do uso de análise de conteúdo e técnicas de triangulação com o software Atlas.ti. Como resultado, o ID através do AAV (ID-AAV doravante) teve um impacto positivo no processo de aprendizagem dos estudantes ao conhecer suas necessidades e aumentar sua motivação. Este estudo sugere que os professores e pesquisadores na Colômbia deveriam implementar ID em suas próprias práticas para entender as vantagens e desvantagens desta abordagem. 0 campo do estudo do inglês como língua estrangeira não pode ser a excepção. A abordagem da ı pode constituir uma alternativa pedagógica valiosa para o benefício dos estudantes.

\section{Palavras chave}

instrução diferenciada (ID); ambiente de aprendizagem virtual (AAV); inglês como língua estrangeira; aprendizagem de línguas

\section{Artículo recibido el 13 de septiembre de 2016 y aprobado el 28 de julio de 2017}

\section{Introduction}

"Traditional instruction has been equated with teachers who teach to the middle or use the one-size-fits-all approach" (Rock, Gregg, Ellis, \& Gable, 2008, as cited in Logan, 2011, p.2). This approach has prevailed due in part to the lack of time or interest of teachers in devoting their efforts to tackle individual learning needs. The advent of new technologies, however, has enabled teachers to resort to multiple tools and applications that contribute to the differentiation purpose. An example of new technological tools is Virtual Learning Environments (VLEs), which consist of a repository that can store many applications as well connect to external websites and many other Internet resources for educational purposes. Likewise, new language learning approaches that focus more on learners rather than on the teacher have emerged to target individualities in the classroom. As an example, we can mention Differentiated Instruction (DI), in which "the teacher must be ready to engage students in instruction through different learning modalities, by appealing to differing interests, and by using varied rates of instruction along with varied degrees of complexity" (Tomlinson, 1999, p. 2). Thus, the use of a VLE and the implementation of a Differentiated Instruction (DI) approach have been combined in the present study to find out their impact on L2 learning.

Although the school targeted in the present study has two English language labs, most lessons do not meet the needs of individual learners (Yang, \& Chen, 2007), according to the findings during the diagnostic stage of the study. On the other hand, despite the fact that there are many research studies demonstrating the effectiveness of DI on students' achievement, and after revising different journals and articles, it seems that many teachers in Colombia, and especially in the Department of Huila, do not take these results into account to provide a differentiated learning environment. Also, there are not many studies that integrate DI and technology to support teaching, promote innovative activities, or to enhance motivation. Hence, the present study intends to answer the following research question: What are the effects of differentiated instruction through an EFL virtual learning environment on the learning process of tenth graders from a private school in the city of Neiva?

In order to answer the research question, we aim to meet the following specific objectives:

- To identify the teacher's role in the development of DI-VLE.

- To characterize the learning environment in the lessons where DI is implemented through a VLE.

- To gain insights on the EFL learning process of students in differentiated lessons through a VLE.

- To learn about students' attitudes and opinions about DI-VLE approach. 


\section{Literature Review}

\section{Differentiated instruction}

DI is an instructional approach that focuses on addressing individual differences, learning styles, intelligences, etc. According to Tomlinson (2005), "[a] key goal of differentiated instruction is maximizing the learning potential of each student" (p. 263). The DI approach constitutes an alternative to provide our students with opportunities to learn according to their interests, learning profiles, or readiness level. Thus, teachers can no longer think of students as being identical subjects of learning, with similar backgrounds, preferences and styles. DI teachers perceive each student as an entire universe and therefore do their best to fit instruction to individual needs. In this regard, Tomlinson (1999) affirms:

They are teachers who strive to do whatever it takes to ensure that struggling and advanced learners, students with varied cultural heritages, and children with different background experiences all grow as much as they possibly can each day, each week, and throughout the year. (p. 2).

Bearing this in mind, this concept allows teachers to adapt the content, process and products of lessons according to each student's readiness, skills, learning style, and interests. This means that the DI approach is flexible in four classroom elements. The first element is the content, which Tomlinson (1999) defines as "what she wants students to learn and the materials or mechanisms through which that is accomplished" (p. 11). According to Tomlinson (2001a), differentiating the content is to provide multiple ways to approach the "facts, concepts, generalizations or principles, attitudes, and skills related to the subject, as well as materials that represent those elements" (p. 7). This emphasis can greatly benefit both the fast and the slow learner, since the amount and depth of the content can be adjusted according to the different learning paces. We can vary the content without losing sight of the course curriculum (Levy, 2008).

The second element is the process; Tomlinson (2001a) states that this is the way that students acquire information or knowledge. The focus of teaching the process is on how students get the information. "To differentiate the process of learning, choices should be provided in expressing the concepts and facts" (Benjamin, 2006; Knowles, 2009; Levy, 2008; as cited in Aliakbari \& Haghighi , 2014). Therefore, students are exposed to activities in which they can maximize their potential according to their learning style.

The third element is the product. Products are vehicles through which students demonstrate and extend what they have learned (Tomlinson 1999, p. 9). Students can demonstrate what they have learned through different activities, whether individual or small group projects, instructional journals, open-ended tasks, tiered assignments, visual presentations, or written assessments. Through a distinct product, students can demonstrate what they have learned (Levy, 162, 2008, p. 162).

The fourth element is the learning environment, a factor that can be modified by the teacher in order to better assist students. The teacher incorporates elements into the classroom to influence and expand students' learning. Tomlinson (2001a) stated that the learning environment is of significant importance in promoting students' achievement (as cited in Aliakbari \& Haghighi, 2014).

Some authors (Mulroy \& Eddinger, 2003; Tomlinson, 2001b; Tomlinson \& Kalbfleisch, 1999; Tuttle, 2000) have also suggested that, in this environment, "each student is valued for his or her unique strengths, while being offered opportunities to demonstrate skills through a variety of assessment techniques" (as cited in Subban, 2006, p. 940).

As previously stated, students vary in readiness, interests, and learning profile. According to Tomlinson (1999), readiness is a student's entry point relative to a particular understanding or skill. It is common to find in our classrooms students who perform way ahead of the average learners, while others may be below the expected level. It is our goal to identify those particular entry points to better shape instruction. Tomlinson (as cited in Subban, 2006, p. 942) argues that "teachers should be able to discern the evolving readiness levels of students in their care and accommodate them by providing tasks that are neither too easy nor too challenging." 
Interests refer to a child's affinity, curiosity, or passion for a particular topic or skill (Tomlinson, 1999, p. 11). Undoubtedly, this constitutes a key factor for instruction. Bearing students' interests in mind will likely help teachers to create more suitable conditions for both teaching and learning processes. MacGillivray and Rueda (as cited in Subban, 2006) proposed that teachers should find ways to engage students by tapping into what interests them, and by involving students in the daily running of the classroom. These procedures confirm the principles of DI towards a more learner-centered approach.

A learning profile has to do with how we learn. It may be shaped by intelligence preferences, gender, culture, or learning style (Tomlinson, 1999, p 11). Based on Tomlinson's ideas, there are four categories of learning-profile factors that teachers can use to plan curriculum and instruction to fit a learner's needs. The goals of learning-profile differentiation are to help individual learners understand the modes of learning that work best for them, and to offer a plethora of options so that each student maximizes his or her learning potential in the classroom (Tomlinson, 1995). The goal of this differentiation factor is raising students' awareness in terms of how they learn more effectively in order to autonomously guide their own learning process.

The underlying chief principle of DI is for both the teacher and the students to know where the latter are in regards to learning, how they better process information, and the necessary conditions to learn and demonstrate what they have learned.

\section{Virtual learning environments}

A Virtual Learning Environment (VLE) functions as an important web-based instructional component in education. Pimentel (1999) defines a VLE as "one that allows learners to perceive the environment, assess situations and performance, perform actions and proceed through experiences and lessons that will allow them to perform better with more experience on repetition on the same task in similar circumstances" (p. 75). In other words, a VLE is a useful tool that allows learners to experience learning by themselves.
A VLE is an opportunity to "normalize" technology in a classroom. It is "the office" of the class.

The VLE used in the present research study is Moodle (Modular Object-Oriented Dynamic Learning Environment), a free open-source learning management system or e-learning platform that serves educators and learners across the globe. This platform has different tools and applications for use, such as chats, forums, discussions, tests, assignments, lessons, wikis and quizzes, among others. Moodle has numerous benefits. For instance, it fosters student learning and facilitates interactions amongst learners, as well as between learners and their teachers (Kavaliauskienè, 2011).

Through the use of VLEs, there is a change from teacher-centered to learner-centered classes. Fotos and Browne (2004) claim that the integration of internet technology and language learning curriculum has changed the focus from teacher-centered classrooms to student-centered environments, giving the learner the power to have control over the lesson content and the learning process. The teacher becomes more of a mediator rather than a tutor. The teacher is a facilitator of the resources while guiding the learning through the discovery of new knowledge.

Thus, the investment of time and effort from the part of the teacher to integrate technology into differentiated lessons can undoubtedly provide significant benefits to the learning process. The Internet is equipped with a plethora of activities and resources that can easily meet the requirements for a DI implementation. Also, the time that teachers invest today on VLE-based lesson plans is time they can save in the future. VLEs have the advantage of storing all class activities, tasks, projects and tests for future adaptations and implementation.

\section{Methodological Design}

This research study follows the main features of Action Research (AR). According to Fraenkel, Wallen, and Hyun (2012), "AR focuses on getting information that will enable teachers to change conditions in a particular situation in which they are personally involved" (p. 14). In addition, O’Brien (2001) 
defines action research as "learning by doing where a group of people identify a problem, do something to resolve it, see how successful their efforts were, and if not satisfied, try again" (p. 1). This kind of research helps to form a better understanding of a particular situation through the implementation of action plan. AR has become the most effective path for teacher researchers to find solutions to common difficulties that emerge in the teaching and learning process.

\section{Participants}

The sample for this study consisted of 29 students from a tenth grade course at a private high school in the city of Neiva. $58.6 \%$ were females (17 students) and $41.4 \%$ were males (12 students) with an age range between 14-17 years old. Both students and parents were informed of all the details of the research study, and they subsequently signed a consent form to participate.

\section{Pedagogical and research instruments}

A qualitative action research (AR) design was conducted over a four-session period. In order to collect information that could guide the planning of differentiated lessons through the use of a VLE, it was necessary to administer the following instruments: a survey that inquired about students' interests; a survey that inquired about students' digital competence; a multiple intelligences test; and two English diagnostic tests that provided information related to the students' readiness level.

A second set of instruments used during the pedagogical intervention consisted of field notes, interviews, and teacher journals. These instruments were used during and after the four sessions of the pedagogical intervention. The field notes format used was composed of two sections: a descriptive and a reflective section. In the descriptive part, the researcher characterized the setting, the participants, and the students' behavior. In the reflective part, the researcher commented on or interpreted what he or she had observed. The interviews were administered to a focus group at the end of each session; these semistructured interviews inquired about the students' opinions and experiences regarding the pedagogical intervention. Different members of the sample group were selected for each of the interviews. The teacher journal served as a personal diary where the teacher could describe significant or dissatisfactory experiences when implementing the DI-VLE. Thus, while the surveys and tests allowed us to collect data that could shape the pedagogical intervention, the interviews, the field notes and the teacher journal provided information that supported the findings, conclusions and recommendations for the study.

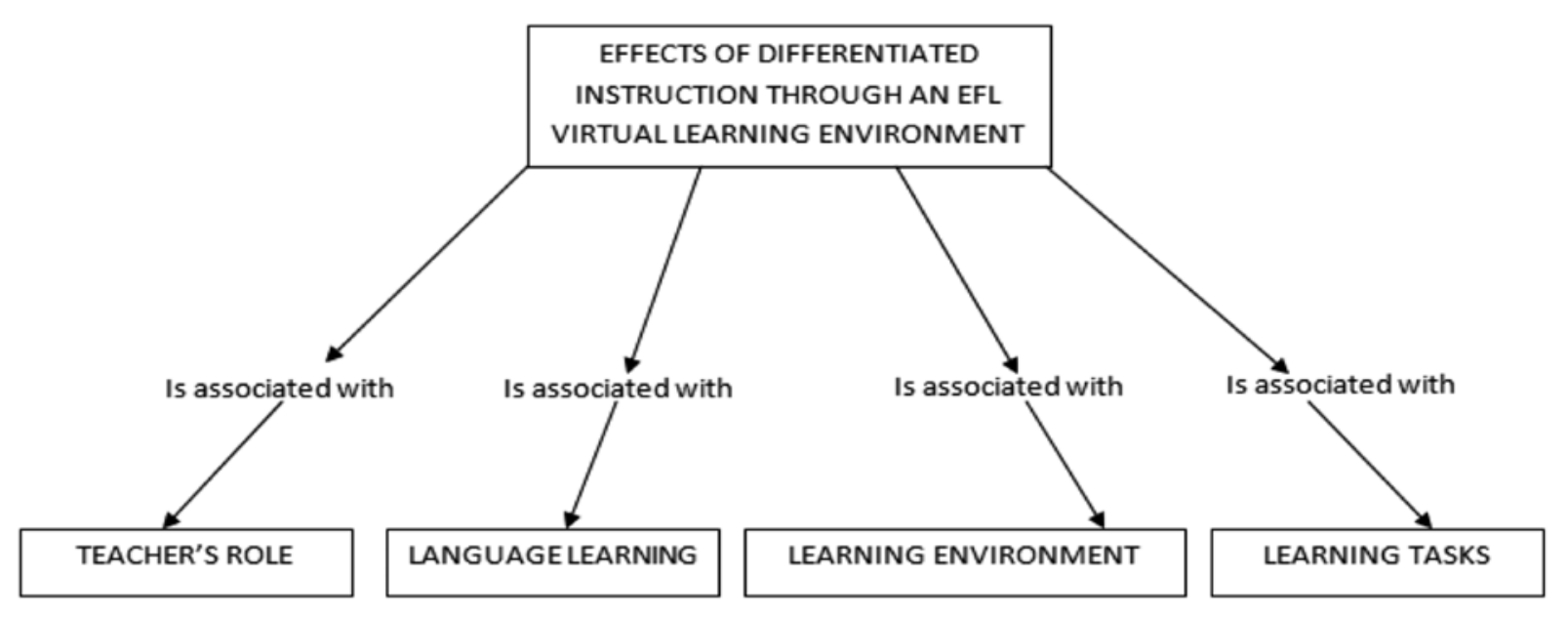

Figure 1. Atlas.ti. Main categories. 


\section{Data Analysis and Findings}

The data analysis process was carried out following content analysis techniques. According to Krippendorff (1989), content analysis is "the use of a replicable and valid method for making specific inferences from text to other properties of the source" (p. 103). For the present study, common characteristics have been identified in the data collected through the instruments for further analyses in relation to the research question. In this regard, Fraenkel, Wallen, and Hyun (2012) state, "a researcher needs to organize a large amount of material by developing appropriate categories, ratings, or scores that can be used for subsequent comparison in order to illuminate what he or she is investigating" (p. 478).

The information collected through the aforementioned instruments was analyzed using the software Atlas.ti. After establishing the coding units, it was necessary to analyze and process these codes to identify the main categories and subcategories that would help to answer the research question. Taking into account this content analysis approach, four main categories were identified, as shown in figure 1 .

The results imply that the implementation of DI-VLE has effects on four main aspects: the teacher's role, language learning, learning environment, and learning tasks. The following is a description of each one of these categories.

\section{Teacher's role}

The different roles that the teacher played during this process can be described as follows:

The teacher as the provider of strategies: The teacher is regarded as that person who cares about students' concerns and difficulties, provides constant feedback and takes actions when necessary. According to analysis made from the field notes, the instructions given at the beginning of each class helped students achieve the main objectives of the lesson. When the teacher provided clear and precise directions before each task, students could perform the activities with greater accuracy and easiness. The following excerpt can evidence this role:
Excerpt 1: "During the development of the class, the teacher's role was essential and relevant, as she encouraged the students building their confidence and friendship to feel more comfortable. Moreover, it should be emphasized how important it was for students the explanation given by the teacher for the development of each activity, besides doing it in a great way, the teacher was very attentive to each student, attending to their concerns and clarifying ideas" (Taken from the field notes).

As seen in the excerpt, the implementation of a DI model requires teachers to have a positive attitude towards students' learning and provides clear directions for class assignments.

The teacher as a problem anticipator: The teacher is always anticipating possible scenarios by having a back-up plan in case difficulties arise. This is very important to consider when working with technology, due to the common breakdowns that occur whether related to the power service or the quality of the Internet. This is also useful in classrooms where students exhibit very different learning paces. The following excerpt evidences the teacher's preparation and planning in those possible scenarios:

E2: "Some extra activities were posted in case some of them finished before the time expected but it did not happen" (Teacher's journal).

E3: "In each activity developed in the classroom, she helped the students all the time with some instructions, explained them some unknown words and gave them ideas about the topic" (Field notes).

As a result of the various technical and contextual challenges that potentially emerge during a lesson, a back-up plan was a crucial aspect in the successful implementation of differentiated lessons through a VLE. The teacher needs to be prepared to tackle any problem regarding technology, materials or the learning process.

The teacher as a facilitator: The DI methodology is student-centered rather than teacher-centered. As a result, the students were in charge of their own learning process, deciding which activities to do according to their learning styles, interests and levels of readiness. The teacher was present 
to help and guide the process, as evidenced in the following excerpt:

E4: "These were activities to practice vocabulary, grammar, listening and writing. In this part, each student was able to choose the activities that he/ she wanted to do according to their learning needs and interests" (Teacher's journal).

When students have the opportunity to choose what they want to learn, they grow in their sense of autonomy. Furthermore, they feel more comfortable with the material they choose which in turn boosters their motivation to learn. In short, the teacher empowers students with learning ownership.

The reflective teacher: The demands of a DI model, along with the use of a VLE, demands teachers to be in constant reflection to better serve the learning needs of their students. It is through reflection that the teacher can find paths to tackle learning issues, as evidenced in the following excerpt:

E5: "I cannot expect all my students to learn the grammar structures of the simple past and the vocabulary of soccer in a single class. I know they need more time to practice, real life situations, and a context in which they can practice what they have learnt. Consequently, I'll plan one more class to continue practicing until I see my students have a more clear idea of the content" (Teacher's journal).

These reflections show the teacher's commitment towards improving students' learning, even if it implies adjusting the timeframe.

The previous roles indicate the relevance of the DI-VLE implementation. Actions such as providing strategies, anticipating problems, facilitating the learning process and reflecting upon every single element of the classes are likely to help students enhance their motivation, self-confidence and autonomous learning.

\section{Language learning}

Two distinct attitudes in students were identified during the process. On the one hand, some students value working with different classmates. This means that some students agree with the idea of sharing with their peers what they know about a topic. Since the change from a teacher-centered perspective to a student-centered perspective is noticeable, a new relationship in the classroom is also evident. It is not just the interaction between the teacher and the students, but also among students, as exemplified in the following excerpt.

E6: “(S23) Pues me pareció interesante, porque podía aprender nuevas cosas de los compañeros, también podría saber cómo que [sic] cosas más les gusta, también podía comunicarme más en inglés, y ayudarnos y yo también aprender" (Focus Group Interview).

When students share their knowledge, feelings, and interests, learning can evolve as a natural, enjoyable and rewarding process because students are not merely focused on how their English is looking, but also on the fact that they are part of a community.

The analysis of the data also showed that participants recognized that classmates' help was an important factor in quest of better results; everyone was able to contribute with their ideas. When participants were completing the activities in the platform, a feeling of comfort and engagement was perceived, perhaps due to the fact that each one of the activities was designed according to individual English proficiency level.

On the other hand, some students rejected peer work. They feel more comfortable working alone because they do not feel the need to clarify what they do not understand. Moreover, students state that when they work alone they focus easily on the different activities in class and they feel they perform better. Excerpts:

E7: “(S3) Pues a mí me gusta trabajar en parejas pero pues haciéndolo sola como que me concentro más y como que así avanzo muy poquito" (Focus Group Interview).

E8: “(S6) Acá es muy chévere porque cuando tiene una palabra ahí y no entiende entonces uno puede preguntarle a una persona, entonces toca interrumpirle la clase a otra persona, ¿no? En el salón, entonces cojo un computador entro a internet y busco la palabra, entonces ahí no interrumpo 
a nadie, trabajo yo y trabajan los compañeros" (Focus Group Interview).

The presence of two distinct attitudes suggests that educators provide different options to choose from while in class. If we analyze the behaviors described above, we can assure that each group of students is different and DI permits the modification of teaching to address such diversity. Even more, the DI approach allows students become more aware of their differences in learning styles, interests, readiness and proficiency levels. They recognize this new methodology as different and interesting because lessons and activities are always varied. In addition, they feel the themes proposed in each lesson were related to their daily life.

Another important effect of the DI-VLE had to do with students' engagement in class. They were aware that the traditional instruction changed because all the activities were quite out of the ordinary. The conventional pen and paper activities in the textbook were replaced with interesting, updated and meaningful activities on the computer.

Furthermore, the data suggest that participants' learning experiences were positive. Learning was reinforced when computers were used as the main tool in the classroom. Students seemed more interested in searching for information, understanding the concepts and communicating what they had learned. Excerpts:

E9: “(S2) Pues a mí me pareció muy divertido, diferente como dice mi compañero, interesante, también aprendimos muchas cosas, vimos fue algo fuera de lo normal porque hicimos hasta una obra de teatro ahí medio le hicimos pues fue como una clase muy didáctica en la cual todos pudimos desenvolvernos así sea manejando un poco el inglés pero que tenemos los conocimientos que adquirimos en el día de hoy, entonces me pareció chévere" (Focus group interview).

During the DI-VLE lessons, we found out that students used a variety of learning resources and strategies. Resources such as online dictionaries, translators, audios, and videos, along with strategies such as repetition and negotiation of meaning were often observed. All these actions significantly supported their language learning. Thus, DI-VLE provides us with many channels to make our classes more interesting and meaningful while giving equal opportunities for the development of our students' L2 skills.

\section{Learning environment}

In the DI classroom, the learning environment influences the learning process of every single student. According to Tomlinson (2001a), "classroom environment in a setting that strives for differentiation is, if anything, even more of a factor in shaping success. A differentiated classroom should support, and is supported by, an evolving community of learners" (p. 21). A differentiated classroom environment encourages students to improve their language abilities and therefore their learning; likewise, students contribute to the learning success of their classmates when they assist each other. According to the participants' statements, the implementation of DI-VLE allows for an effective learning environment.

It is important to clarify that the learning environment during the four sessions of the study was different from the environment of a traditional classroom with just chairs and a whiteboard. A computer lab was used because of the VLE approach, and therefore special arrangements were made. First, participants were divided into three groups according to their English proficiency level: beginner, intermediate and advanced. Yet groups were not given these names but rather color names (green, yellow and orange) to avoid affecting the students' confidence levels. Second, participants could sit wherever they wanted, a pattern that is not quite common in regular classes, but which may render great benefits. As Tomlinson (1999) claims, "flexible and comfortable seating options provide a kind of welcome as well" (p. 21). Third, the learning environment was enjoyable and interesting for students because content and topics used in the platform were chosen according to their interests. In fact, they were given the opportunity to choose the content and the process. This kind of flexibility provided by 
the use of a VLE contributes to students' growing autonomy and love of learning. Additionally, we can affirm that the place where the lessons took place (English lab) contributed significantly to students' enhanced motivation due to their high interest in technology.

As students' interest in class activities grew, they began to participate more. They asked for help every time they needed because they were in a group where all the students had the same language proficiency level and supported each other when necessary. In this regard, Tomlinson (1999) assures,

Safety means that when I try a new skill, expend effort, or take a risk with a creative idea, I won't be thought of as foolish or stupid. Safety happens when you feel accepted as you are, and valued enough so that people want to help you become even better. (p. 22).

In the following excerpt, we can evidence how students' participation was influenced in the DI classroom:

E10: "[T]he academic environment was very energetic, as students arrived happy and very anxious to receive the class. They settled into their places quickly and put all their attention on their learning process. And thanks to the students interest in the development of the class, it was possible to obtain constant participation from them" (Field notes).

Tomlinson (1999) states that a meaningful contribution from every group member "is not likely to occur when some members of the group have all the answers and skills and others clearly have a comparative deficit in knowledge and skills" (p. 26). Based on this statement, it seems fair to suggest that a more meaningful and comfortable environment in the classroom was fostered as a result of participants working with a partner at a similar readiness level.

On the other hand, a closer look at the data indicates that when DI-VLE is implemented, it is important to establish the context before the lessons takes place. From the experience of the present research process, we believe that a satisfactory learning environment is promoted if the teacher prepares the equipment, materials and activities in advance. In other words, improvisation will hardly foster effective learning environments.

On the other hand, there were a few participants that felt unsettled by the drastic change from a traditional classroom setting to a DI approach. This reaction was due perhaps to their already established comfort level with traditional instruction.

In brief, the learning environment becomes an essential factor in the implementation of DI-VLE. Cooperation and collaboration were strengthened in part because students had the opportunity to work with partners that were at a similar readiness level. Students felt more comfortable because they could participate in different activities with no fear of showing their linguistic skills. Thus, it can be concluded that the classroom environment herein depicted allows for the development of students' confidence and learning.

\section{Learning tasks}

The planning and development of learning tasks in DI-VLE have to be carried out based on the particular knowledge and skills of students. Heacox argued that, "when differentiating the content, the teacher considers what students already know and adapts the curriculum content to be presented accordingly. The teacher may choose to eliminate content or introduce certain content earlier, depending on the pace of student mastery" (as cited in WilliamsBlack, Bailey, \& Coleman-Lawson, 2010). Hence, it might be stated that the implementation of DI-VLE also showed a positive effect on the tasks themselves. For instance, the students described the tasks as more engaging and different than the regular English classes they have. They showed positive attitudes towards the different activities proposed by the teacher on the VLE. Excerpt:

E11: (S23) "Ehh pues lo q [sic] escribí, lo q [sic] escribimos fue que una experiencia muy buena, pudimos tener un ambiente diferente al de todas las clases" (Focus Group Interview).

E12: "I could see most of the students were very concentrated developing each activity and this is 
a positive issue, which means that each student was motivated in the class" (Teacher's journal).

As Smith and Throne (2009) highlight, "constructivists believe learning is most meaningful when topics are connected to students' needs and interests, and when the students themselves are actively engaged in creating, understanding, and connecting with knowledge" (p. 31). In the DI-VLE, the students had the chance to choose the different activities they wanted to do according to their preferences and learning styles. There is compelling evidence that students liked the way the activities were planned.

E13: "(S1) Me gusto [sic] al final, en la última actividad porque nosotros teníamos la opción de cómo queríamos trabajar. Yo escogí la parte de la caricatura, pero pues es un video animado, pero pues por falta de tiempo uno no lo completa" (Focus Group Interview).

E14: "The topic caught the attention of the students and kept them motivated all along. And it made so enjoyable the environment in the classroom" (Field notes).

Technology not only allows teachers to modify different elements of the learning process such as content, the process, the task or the product, but it also has the power to influence our students positively. It was evident that the DI-VLE intervention attracted students' interest and attention, as can be read in the following reflection by one of the participants:

E15: “(S6) A mí me parece como más dinámico, y no tanto como que al libro, yo entiendo mucho mejor en un computador que clavado en un libro, ahí pegado mirando, yo creo que encuentro una palabra que no me la sepa... uno se va al computador y se lo facilita mucho más, y cada uno tiene lo suyo por ejemplo si yo tengo mi computador y yo voy a colocar algo a escuchar en youtube, pues ya es como mi problema si yo no desarrollo la actividad, es cosa de cada uno, eso ya es como responsabilidad de cada uno y es como un tema un campo inexplorable (inexplorado) para la clase de inglés o para las demás clases, porque siempre lo rutinario, como que... a lo antiguo diría yo" (Focus Group Interview).
The materials used in the DI-VLE played a vital role in the learning process. These materials consisted of VLE applications in conjunction with CD players, handouts, and the like. According to participants, the appropriate use of the materials encouraged them to learn English.

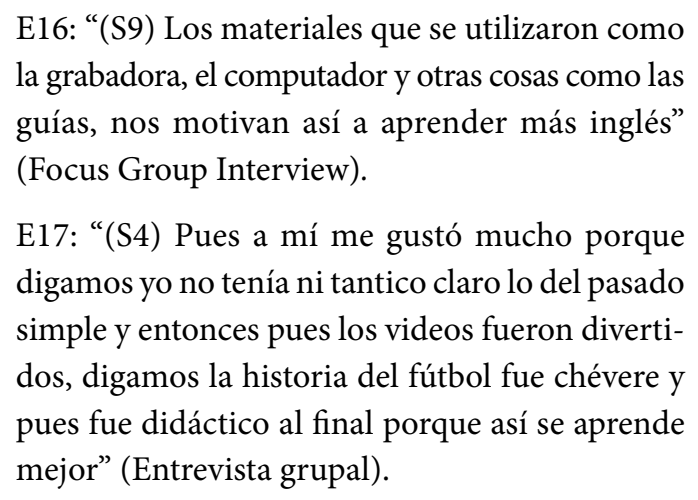

The DI-VLE also showed an effect on students' sense of independence. Students had the resources, activities, materials and time to work at their own pace. Furthermore, students were given the chance to choose the partners they wanted to work with. Yet, many of them preferred to work alone, and the effect of working with a classmate or working alone showed a pattern.

E18: "It could be noticed that the few students who worked in pairs, took more time in completing the virtual activities possibly due to their low level of English. While those who worked alone, were those who demonstrated a high level of English and quickly finished the activities" (Field notes).

Those working alone somehow demonstrated confidence to complete the different class activities, and for the most part they did it successfully. Another positive effect is that students could easily manage the VLE and the different applications after the first explanation of the activities. Once they started working on their computers, they tended to focus more and stayed on task.

E19: "Most of them showed skills at using the online platform" (Field notes).

There were also some threats to the smooth implementation of the DI-VLE. On the one hand, there were technical problems related to poor internet con- 
nection, some computers broke down and sometimes the activities in the platform were blocked. In these cases, the teacher's response was very important in how fast these issues were tackled without affecting the concentration of students. On the other hand, at the beginning of the process, some students showed poor behavior because they either finished the tasks before the rest of the students or got distracted by visiting other web pages on the computer. The following excerpts illustrate these situations:

E20: "On top of that, the advanced and intermediate students finished the task and started making noise and walking around the classroom disturbing their classmates" (Field notes).

E21: "In some cases, they got distracted by the videos and I had to guide them to the activity again" (Teacher's journal).

Despite the beauty of new technologies, the teacher must be always ready to solve the problems that may threaten the learning process. That is why planning is a key element of any language teaching approach.

After analyzing the four categories, we can affirm that the implementation of DI brings positive changes to the EFL learning process. Students feel more comfortable because the different tasks are planned according to their interests, learning styles, and level of readiness. It is evident that students enjoyed performing the tasks in the VLE while learning at their own pace. Furthermore, the different roles the teacher played become fundamental for the successful implementation of DI. Actions like providing strategies, anticipating the problems, facilitating the learning process, and reflecting upon each element of the lessons promote a comfortable classroom environment towards a more successful learning process.

\section{Conclusions and Pedagogical Implications}

It is clear from the analysis above that the promotion of DI-VLE had an impact on the teacher's role, the learning tasks, the learning environment and the language learning process.
The teacher performed crucial roles that significantly impacted the teaching and learning process. The "provider of strategies" role evidenced the teacher's interest in helping students cope with difficulties when working on the different activities in the VLE. The "problem anticipator" role showed the teacher's commitment with the lesson planning and therefore with students' learning. In the "facilitator" role, the teacher guided and helped students throughout the performance of all class activities. Lastly, the "reflective teacher" role evidenced the teacher's constant examination on how to solve the different constraints presented during the lessons and make changes during the pedagogical intervention. Despite the fact that there can be many difficulties in the lessons where DI-VLE is implemented, the proactive attitude of the teacher towards these constraints is crucial to overcome them.

DI promoted a suitable learning environment that enhanced students' self-confidence and collaborative work. The students recognized that their learning is reinforced while interacting with classmates because they can share different points of view and knowledge. Furthermore, a VLE-based language teaching methodology fosters students' engagement because they feel comfortable using technological tools. It is clear that most of our students are not indifferent to new technologies, which is why they are even known in the literature as "digital natives." Students feel more confident and useful if the platform provides clear instructions about what to do, how to do it and what is expected of them.

The implementation of DI-VLE fosters autonomous learning since students are in charge of their own learning process. Students have the opportunity to choose the content, the process and the product according to their interests and skills. It helps them to approach the new concepts or skills with a more confident and autonomous attitude. This type of methodology encourages students to resort to different resources and strategies that facilitate their learning. For instance, students used online dictionaries, translators, music, videos, as well as negotiation of meaning and repetition as learning strategies in most classes. 
The findings of this study are based on the assumption that students' differences turn into meaningful factors for the teaching and learning process. In this regard, Tomlinson (2001a) states:

What we share in common makes us human. How we differ makes us individuals. In a classroom with little or no differentiated instruction, only student similarities seem to take center stage. In a differentiated classroom, commonalities are acknowledged and built upon. (p.1).

However, these differences are not generally taken into account when teachers plan, develop and assess their classes. A traditional instruction approach is commonly followed in today's classrooms, in which all students are expected to learn in the same way, have the same interests and respond alike. As already stated throughout this text, the DI-VLE offers many possible strategies and tools to implement in our teaching practice, based on students' readiness, interests, and learning profiles, bringing outstanding learning benefits.

Some inquiries emerge after this research study: why do teachers keep teaching in the same way? Why do teachers not reflect on their teaching practices and try to implement changes that target particular learning styles? What reasons are behind a teacher's resistance to find such alternatives?

If teachers reflect on their daily teaching practices, they might find multiple threats and problems in students' learning process. DI-VLE can therefore become the alternative response to those threats. The incorporation of technology in the DI approach can guarantee not only engagement for our students, but also learning effectiveness.

Although DI may appear as time consuming, every single effort to differentiate our teaching-learning practices is one step closer to maximizing our students' potential. Besides, the time invested by teachers today can be time saved in the future.

In conclusion, this study highlights that the DI-VLE approach can be a great alternative to traditional English teaching methodologies, which regularly focus on pen and paper, textbook or white- board activities. Besides, this alternative allows us to shift from a teacher-centered to a more studentcentered approach.

Thus, provided that further empirical studies support the results yielded by this study, our professional community should purposefully consider DI-VLE as a powerful teaching alternative that will eventually contribute to students' language learning success.

\section{References}

Aliakbari, M., \& Haghighi, J. (2014). On the effectiveness of differentiated instruction in the enhancement of Iranian learners reading comprehension in separate gender education. Procedia - Social and Behavioral Sciences, 98, 182-189. Available at www.sciencedirect.com.

Ching Yang, C. (2007). Technology-enhanced language learning: A case study. Computers in Human Behavior, 23, 860-879. Available at www.sciencedirect.com

Fotos, S., \& Browne, C. (2004). The development of CALL and current options. In S. Fotos, \& C. M. Browne (Eds.), New perspectives on CALL for second language classrooms (pp. 3-14). Mahwah, NJ: Lawrence Erlbaum Associates.

Fraenkel, J. R., Wallen, N. E., \& Hyun, H. H. (2012). How to design and evaluate research in education ( $8^{\text {th }} \mathrm{Ed}$.). New York, NY: McGraw-Hill.

Kavaliauskienè, G. (2011). Moodle in English for specific purposes at Mykolas Romeris University, Socialinis Darios, 10(1), 112. Moodle docs. http:// www.moodlerooms.com/community-initiatives/ what-is-moodle.

Krippendorff, K. (1989). Models of messages: Three prototypes. In G. Gerbner, O. R. Holsti, K. Krippendorff, G. J. Paisly, \& Ph.j Stone (Eds.), The analysis of communication content. New York, NY: Wiley.

Levy, H. (2008). Meeting the needs of all learners through differentiated instruction: Helping every child reach and exceed standards, 81(4), 161-164.

Logan, B. (2011). Examining Differentiated instruction: teachers respond. Research in higher education journal, 13, 1-14.

O’Brien, J. R. (2001). Um exame da abordagem metodológica da pesquisa ação [An overview of the methodological approach of action research]. In R. Richardson (Ed.), Teoria e prática da pesquisa ação 
Promotion of Differentiated Instruction Through a Virtual Learning Environment

Marolly Andrea Vargas-Parra / Javier Armando Rodríguez-Orejuela / Leonardo Herrera-Mosquera

[Theory and practice of action research]. João Pessoa, Brazil: Universidade Federal da Paraíba. Available at http://www.web.ca/ robrien/papers/arfinal.html

Pimentel, J. R. (1999). Design of net-learning systems based on experiential learning. Journal of Asynchronous Learning Networks, 3(2), 64-90. Retrieved from http:// www.aln.org/publications/jaln/v3n2/v3n2_pimentel.asp

Rock, M. L., Gregg, M., Ellis, E., \& Gable, R. A. (2008). Reach: A framework for differentiating classroom instruction. Preventing School Failure, 52(2), 31-47.

Smith, G., \& Throne, S. (2009). Differentiating instruction with technology in middle school classrooms. Washington, DC: International Society for Technology in Education.

Subban, P. (2006). Differentiated instruction: A research basis. International Education Journal, 7(7), 935-947.

Tomlinson, C. A. (1995). How to differentiate instruction in mixed ability classrooms. Alexandria, VA: ASCD.
Tomlinson, C. A. (1999). The differentiated classroom: Responding to the needs of all learners. Alexandria, VA: Association for Supervision and Curriculum Development.

Tomlinson, C. A. (2001a). How to differentiate instruction in mixed-ability classrooms ( $2^{\text {nd }}$ Ed.). Alexandria, VA: Association for Supervision and Curriculum Development.

Tomlinson, C. A. (2001b). Differentiated instruction in the regular classroom. Understanding Our Gifted, 14(1), 3-6.

Tomlinson, C. A. (2005). Grading and differentiation: Paradox or good practice? ProQuest Education Journals, 44(3), 262-269.

Williams-Black, T. H, Bailey, J. P., \& Coleman-Lawson, P. D. (2010). Differentiated instruction: Are university reading professors implementing it? The Reading Matrix, 10(1), 45-54. 